\title{
Communication
}

\section{The Analyses of High Infectivity Mechanism of SARS-CoV-2 and Its Variants}

\author{
Yonghua Lu ${ }^{1,2}$, Tianfu Zhao ${ }^{1,2}$, Ming Lu ${ }^{2}$, Yaopeng Zhang ${ }^{3}$, Xiang Yao ${ }^{3}$, Guoyi $\mathrm{Wu}^{4}{ }^{4}$, Fangyin Dai ${ }^{1}$, \\ Fengxiu Zhang ${ }^{5}$ and Guangxian Zhang $1,2, * \mathbb{B}$
}

check for updates

Citation: Lu, Y.; Zhao, T.; Lu, M.; Zhang, Y.; Yao, X.; Wu, G.; Dai, F.; Zhang, F.; Zhang, G. The Analyses of High Infectivity Mechanism of SARS-CoV-2 and Its Variants. COVID 2021, 1, 666-673. https://doi.org/ $10.3390 /$ covid 1040054

Academic Editor: Giuseppe Novelli

Received: 25 September 2021

Accepted: 2 November 2021

Published: 24 November 2021

Publisher's Note: MDPI stays neutral with regard to jurisdictional claims in published maps and institutional affiliations.

Copyright: (c) 2021 by the authors. Licensee MDPI, Basel, Switzerland. This article is an open access article distributed under the terms and conditions of the Creative Commons Attribution (CC BY) license (https:// creativecommons.org/licenses/by/ $4.0 /)$.
1 State Key Laboratory of Silkworm Genome Biology, College of Sericulture Textile and Biomass Sciences, Southwest University, No.2 Tiansheng Street, Beibei, Chongqing 400715, China; lyh1249959090@163.com (Y.L.); zhaotf@swu.edu.cn (T.Z.); fydai@swu.edu.cn (F.D.)

2 Chongqing Engineering Research Center of Biomaterial Fiber and Modern Textile, No. 2 Tiansheng Street, Beibei, Chongqing 400715, China; lumingswu@163.com

3 State Key Laboratory for Modification of Chemical Fibers and Polymer Materials, Shanghai Belt and Road Joint Laboratory of Advanced Fiber and Low-Dimension Materials, College of Materials Science and Engineering, Donghua University, Shanghai 201620, China; zyp@dhu.edu.cn (Y.Z.); yaoxiang@dhu.edu.cn (X.Y.)

4 Shanghai Public Health Clinical Center, Fudan University, 2901 Caolang Road, Shanghai 201508, China; wuguoyi@163.com

5 Institute of Bio-Organic and Medicinal Chemistry, College of Chemistry and Chemical Engineering, Southwest University, Chongqing 400715, China; zhangfx656472@sina.com

* Correspondence: zgx656472@sina.com

Abstract: SARS-CoV-2 has high infectivity and some of its variants have higher transmissibility. To explore the high infectivity mechanism, the charge distributions of SARS-CoV, SARS-CoV-2, and variants of concern were calculated through a series of net charge calculation formulas. The results showed that the SARS-CoV-2 spike protein had more positive charges than that of SARS-CoV. Further results showed that the variants had similar but higher positive charges than preexisting SARS-CoV-2. In particular, the Delta variant had the greatest increase in positive charges in $S_{1}$ resulting in the highest infectivity. In particular, the $S_{1}$ positive charge increased greatly in the Delta variant. The $S_{1}$ positive charge increased, and due to the large negative charge of angiotensin-converting enzyme- 2 (ACE2), this resulted in a large increase in Coulomb's force between $S_{1}$ and ACE2. This finding agrees with the expectation that the positive charges in the spike protein result in more negative charges on SARS-CoV-2 antibodies than that of SARS-CoV. Thus, the infectivity of a novel SARS-CoV-2 variant may be evaluated preliminarily by calculating the charge distribution.

Keywords: SARS-CoV-2; SARS-CoV; ACE2; antibodies; infectivity; charge distributions

\section{Introduction}

Since the initial emergence of the novel coronavirus (SARS-CoV-2) infection, the coronavirus COVID-19 pandemic has been expanding nationwide and globally for over a year [1-3]. Although there is only a $22.5 \%$ difference in amino acid sequence between SARS-CoV-2 and SARS-CoV [4], SARS-CoV-2 has much higher infectivity than SARS-CoV, and a series of SARS-CoV-2 variants, such as the Alpha, B.1.1.7 + E484K, Beta, Gamma, and Delta variants, have much higher infectivity than the preexisting SARS-CoV-2 [5-9]. In particular, the Delta variant is present in countries and territories worldwide. Wrapp et al. reported that SARS-CoV-2 has a higher affinity for angiotensin-converting enzyme-2 (ACE2) than that of SARS-CoV. However, they did not discuss the reason for the high infectivity. Some reports have suggested that there is a mutation "PRRA" in SARS-CoV-2, making the SARS-CoV-2 spike protein can be cleaved and allowing SARS-CoV-2 to enter the cell faster [10-14]. Many studies have focused on SARS-CoV-2 and its high infectivity rate, but investigations into the mechanism of the highly infectious SARS-CoV-2 and its variants 
are limited, particularly the Delta variant [15-23]. Obviously, revealing the high infectivity spike protein structure mechanism is very important for designing the medicine structures.

The interactions that occur between organic molecules are mainly Coulomb forces, hydrogen bonding forces, polar groups, and van der Waals forces. Among them, the Coulomb force is a major long-distance interaction that should be analyzed between SARS-CoV-2 (GenBank: QHU36824.1) [10,15] and ACE2 (GenBank: ACT66268.1) [10,24]. Therefore, in this study, we analyzed the charge distributions of SARS-CoV (GenBank: AAP13441.1) [10,15], SARS-CoV-2, some highly infectious SARS-CoV-2 variants, and numerous SARS-CoV and SARS-CoV-2 antibodies. The results suggest that SARS-CoV-2 and its variants have high Coulomb attraction to ACE2.

\section{Methods}

The charges of the various proteins were calculated using Equations (1) and (2) [25]:

$$
X=\sum_{i=1}^{2} \frac{K_{a i} m_{i}}{\left[H^{+}\right]+K a i}
$$

where $X$ is the negative charge number of the protein and $K_{a i}$ expresses the ionization constant of an acidic amino acid residue. In a protein, glutamic acid residues and aspartic acid residues ionize $H^{+}$resulting in negative charges. Finally, $m_{i}$ is the number of acidic amino acid residues in the protein:

$$
Y=\sum_{i=1}^{3} \frac{\left[H^{+}\right] n_{i}}{\left[H^{+}\right]+K b i}
$$

where $Y$ is the positive charge number of a protein and $K_{b i}$ is the ionization constant of a basic amino acid residue. In a protein, only arginine, lysine, and histidine residues combine with $\mathrm{H}^{+}$to produce positive charges. $n_{i}$ represents the number of basic amino acid residues in the protein.

The net charge number $(H)$ of a protein is calculated by Equation (3) as follows:

$$
H=Y-X
$$

The calculation deviation is shown as Equations (4) and (5):

$$
\Delta X=\sum_{i=1}^{2} \frac{\left[H^{+}\right] m_{i}}{\left(\left[H^{+}\right]+K a i\right)^{2}} \Delta K_{a i}
$$

where $\Delta X$ expresses the deviation in the negative charge of a protein and $\Delta K_{a i}$ is the deviation in $K_{a i}$

$$
\Delta Y=\sum_{i=1}^{3} \frac{\left[H^{+}\right] n_{i}}{\left(\left[H^{+}\right]+K_{b i}\right)^{2}} \Delta K_{b i}
$$

where $\Delta Y$ is the deviation in the positive charge of a protein and $\Delta \mathrm{K}_{\mathrm{bi}}$ is the deviation in $K_{b i}$.

The $K_{a i}, K_{b i}$, and $\Delta K_{b i}$ values are listed in Table 1.

Table 1. The ionization constant parameters.

\begin{tabular}{cccccccc}
\hline $\begin{array}{c}\text { Acidic } \\
\text { Amino Acid }\end{array}$ & $\mathbf{K}_{a i}$ & $\Delta \mathbf{K}_{a i}$ & $\mathbf{p K} \boldsymbol{K}_{\boldsymbol{a} i}$ & $\begin{array}{c}\text { Basic } \\
\text { Amino Acid }\end{array}$ & $\mathbf{K}_{b i}$ & $\boldsymbol{\Delta} \mathbf{K}_{b i}$ & $\mathbf{p K}_{b i}$ \\
\hline Glu & $3.98 \times 10^{-5}$ & 0 & 4.4 & Arg & $1.38 \times 10^{-12}$ & $1.13 \times 10^{-12}$ & $11.6-12.6$ \\
Asp & $5.1 \times 10^{-4}$ & $4.9 \times 10^{-4}$ & $3.0-4.7$ & Lys & $2.12 \times 10^{-10}$ & $1.86 \times 10^{-10}$ & $9.4-10.6$ \\
- & - & - & - & His & $1.31 \times 10^{-6}$ & $1.2 \times 10^{-6}$ & $5.6-7.0$ \\
\hline
\end{tabular}

The values of the ionization constant $\mathrm{K}_{a i}$ and $\mathrm{K}_{b i}$ were calculated from $\mathrm{pK}_{a i}$ and $\mathrm{pK}_{b i}$ [26] because the $\mathrm{pK}$ values are not constant in a protein, and $\mathrm{K}_{a i}$ and $\mathrm{K}_{b i}$ are the average values. The $\Delta \mathrm{K}$ value is the difference between the maximum $\mathrm{K}_{a i}$ or $\mathrm{K}_{b i}$ and the average value. 


\section{Results and Discussion}

\subsection{The Charge Distributions of SARS-CoV-2, SARS-CoV, and ACE2}

The spike proteins of the SARS-CoV-2 $\left(\mathrm{S}_{\mathrm{p}}\right)$ and SARS-CoV $\left(\mathrm{S}_{\mathrm{s}}\right)$ viruses consist of two subunits $\left(S_{1}\right.$ and $\left.S_{2}\right)$. The $S_{1}$ domain is $13-685$ amino acids in the sequence of the spike protein from the N-terminal domain, and $S_{2}$ is the 686 amino acids to the end $[7,15,27]$. The numbers of acidic and basic amino acid residues in every section of the SARS-CoV-2 and SARS-CoV spike proteins, as well as in ACE2, are listed in Table 2.

Table 2. The numbers of acidic and basic amino acid residues in the sections of the spike proteins of SARS-CoV-2, SARS-CoV, as well as in ACE2.

\begin{tabular}{cccccccc}
\hline Amino Acid & S1 & S2 & Sp & Ss1 & Ss2 & Ss & ACE2 \\
\hline Glu & 23 & 25 & 48 & 17 & 25 & 42 & 56 \\
Asp & 31 & 31 & 62 & 45 & 28 & 73 & 43 \\
Arg & 29 & 13 & 42 & 23 & 16 & 39 & 31 \\
Lys & 30 & 31 & 61 & 31 & 29 & 60 & 47 \\
His & 9 & 8 & 17 & 9 & 6 & 15 & 16 \\
\hline
\end{tabular}

The charge numbers and calculated deviations of the spike proteins in SARS-CoV2, SARS-CoV, and ACE2 at different $\mathrm{pH}$ values are presented in Table 3. As the $\mathrm{pH}$ of human blood is 7.25-7.35, the charge numbers of the proteins at the median $\mathrm{pH}$ of 7.3 are of particular interest. Table 3 shows that all of the above protein macromolecules have negative charges at $\mathrm{pH}$ 7.3. Intriguingly, the $\mathrm{S}_{\mathrm{p}}$ charge number decreased significantly compared with that of $S_{s}$. Table 3 also shows that the deviations in the charges at $\mathrm{pH} 7.3$ are sufficiently low to determine the accuracy of the calculation.

Table 3. The charge numbers of $S_{p}, S_{s}$, and the ACE2 protein at different $\mathrm{pH}$ values.

\begin{tabular}{ccccccccc}
\hline $\mathbf{p H}$ & $\mathbf{5 . 0}$ & $\mathbf{5 . 5}$ & $\mathbf{6 . 0}$ & $\mathbf{6 . 5}$ & $\mathbf{7 . 0}$ & $\mathbf{7 . 3}$ & $\mathbf{8 . 0}$ & $\mathbf{8 . 5}$ \\
\hline$H_{\mathrm{Sp}}$ & 18.9 & 8.9 & 1.6 & -3.3 & -5.8 & $\mathbf{- 6 . 6}$ & -8.1 & -10.8 \\
$\Delta H_{\mathrm{Sp}}$ & \pm 2.7 & \pm 3.6 & \pm 4.0 & \pm 2.5 & \pm 1.1 & $\pm \mathbf{0 . 8}$ & \pm 1.2 & \pm 3.2 \\
$H_{\mathrm{Ss}}$ & 7.1 & -1.9 & -8.3 & -12.7 & -14.9 & $\mathbf{- 1 5 . 6}$ & -17.1 & -19.7 \\
$\Delta H_{\mathrm{SS}}$ & \pm 2.7 & \pm 3.3 & \pm 3.5 & \pm 2.2 & \pm 1.0 & $\pm \mathbf{0 . 7}$ & \pm 1.2 & \pm 7.6 \\
$H_{\mathrm{ACE} 2}$ & 5.2 & -5.3 & -12.6 & -17.5 & -19.8 & $\mathbf{- 2 0 . 5}$ & -21.8 & -23.9 \\
$\Delta H_{\mathrm{ACE} 2}$ & \pm 2.3 & \pm 3.3 & \pm 3.7 & \pm 2.3 & \pm 1.1 & $\pm \mathbf{0 . 7}$ & \pm 0.95 & \pm 2.5 \\
\hline
\end{tabular}

Although $\mathrm{S}_{\mathrm{p}}$ and $\mathrm{S}_{\mathrm{s}}$ had negative charges at $\mathrm{pH} 7.3$, the charges may not be distributed uniformly throughout the proteins as the amino acid sequences varied. $S_{1}$ had six more Arg and one fewer Lys compared with $\mathrm{S}_{\mathrm{s} 1}$, which have positive charges, and had six more Glu and fourteen fewer Asp, which have negative charges, and $S_{2}$ had two more His, two more Lys, three more Asp, and three fewer Arg than $\mathrm{Ss}_{2}$. Although the $\mathrm{S}_{\mathrm{s}}$ and $\mathrm{S}_{\mathrm{p}}$ amino acid sequences are only slightly different, some of the amino acids that differ are the key acidic and basic amino acids. Therefore, the calculations are based on more accurate modules. Besides the two subunits, the receptor-binding domain (RBD) of each subunit was also calculated. The $S_{p}$ RBD was 319-541 amino acids [7] and that of $S_{s}$ was 306-527 amino acids [27]. All charge numbers are listed in Table 4.

Table 4. Charge distributions in the $S_{\mathrm{p}}$ and $S_{\mathrm{s}}$ sections.

\begin{tabular}{cccccccccc}
\hline $\mathbf{p H}$ & $\mathbf{5 . 0}$ & $\mathbf{5 . 5}$ & $\mathbf{6 . 0}$ & $\mathbf{6 . 5}$ & $\mathbf{7 . 0}$ & $\mathbf{7 . 3}$ & $\mathbf{8 . 0}$ & $\mathbf{8 . 5}$ \\
\hline $\mathrm{S}_{\mathrm{p}}(\mathrm{RBD})$ & 8.5 & 7.3 & 6.6 & 6.3 & 6.1 & $\mathbf{6 . 0}$ & 5.8 & 5.2 \\
$\mathrm{~S}_{1}$ & 18.2 & 13.2 & 9.5 & 6.9 & 5.6 & $\mathbf{5 . 2}$ & 4.4 & 3.1 \\
$\mathrm{~S}_{2}$ & 0.7 & -4.3 & -7.9 & -10.2 & -11.4 & $-\mathbf{1 1 . 8}$ & -12.6 & -13.9 \\
$\mathrm{~S}_{\mathrm{s}}(\mathrm{RBD})$ & 4.9 & 4.1 & 3.5 & 3.2 & 3.1 & $\mathbf{4 . 0}$ & 2.8 & 2.2 \\
$\mathrm{~S}_{\mathrm{s} 1}$ & 4.2 & -0.1 & -3.6 & -6.1 & -7.4 & $-\mathbf{7 . 8}$ & -8.6 & -9.9 \\
$\mathrm{~S}_{\mathrm{s} 2}$ & 2.9 & -1.7 & -4.7 & -6.6 & -7.6 & $\mathbf{- 7 . 9}$ & -8.5 & -9.8 \\
\hline
\end{tabular}

Table 4 shows that the charge distributions were highly uneven in $\mathrm{S}_{\mathrm{p}}$ and $\mathrm{S}_{\mathrm{s}}$, which is consistent with the predicted results. $S_{\mathrm{s} 1}$ and $S_{\mathrm{s} 2}$ almost had the same number of negative charges at -7.8 and -7.9 , respectively. Additionally, $S_{1}$ unexpectedly had a positive charge of 5.2, while $S_{2}$ had a much higher negative charge of - 11.8 than that of $\mathrm{S}_{\mathrm{s} 1}$ and $\mathrm{S}_{\mathrm{s} 2}$. 
The net charge distributions of the spike protein in SARS-CoV-2, SARS-CoV, and the interactions between the spike protein and ACE2 are shown in Figure 1. The binding part of SARS-CoV-2 during the infection process is $S_{1}$, as shown in Figure $1 b$. $S_{1}$ was positively charged, while ACE2 had many negative charges that will generate two effects. The $S_{1}$ positive charges are attracted by ACE2 over a relatively long distance because the Coulomb interactions do not need a specific structured area. This means that the ACE2 receptor attracts SARS-CoV-2 easily causing enhanced transmissibility. However, the affinity between $S_{p}$ and ACE2 was relatively strong due to the Coulomb interactions between the positive and negative charges, so as long as SARS CoV-2 is bound to ACE2, they are difficult to separate. Certainly, after the SARS CoV-2 combined the ACE2, there were hydrogen bonding forces, polar groups, and van der Waals forces between SARS CoV-2 and ACE2.
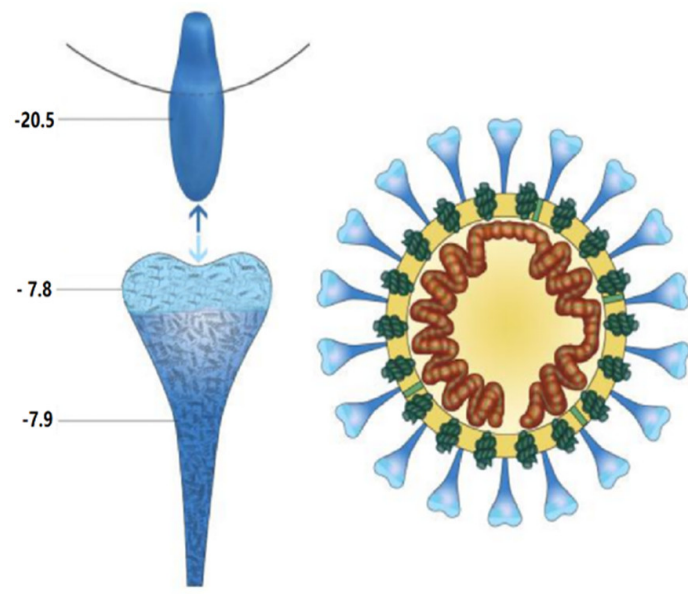

(a)

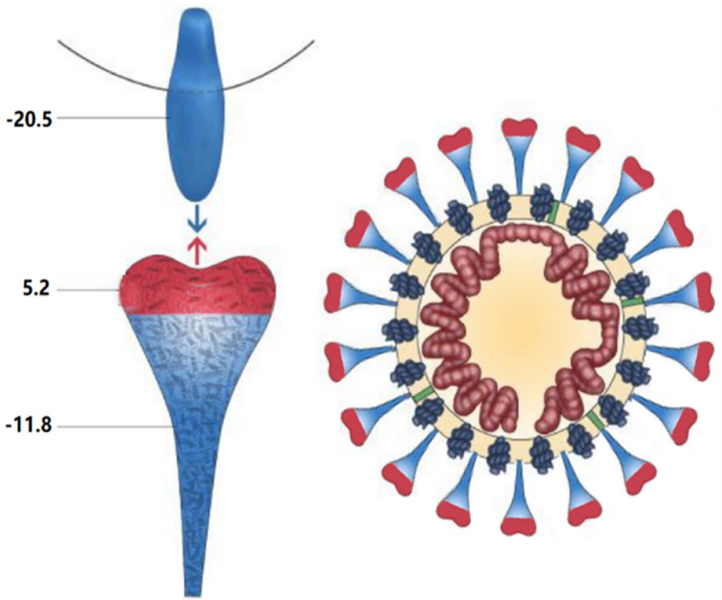

(b)

Figure 1. Distributions of the net charges of the SARS-CoV (a) and SARS-CoV-2 (b) spike proteins and the interactions between the spike proteins and ACE2. Blue represents the part of protein with a negative net charge and red expresses the part of the protein with a positive net charge.

Based on these results, we speculate that because the first section $S_{1}$ had positive charges and ACE2 had negative charges, $S_{p}$ will tightly combine with ACE2. This speculation follows the result of Wrapp et al. that $S_{p}$ and ACE2 have high affinity [10].

\subsection{Analysis of the SARS-CoV-2 Variants}

Many SARS-CoV-2 variants have been detected worldwide, as well as some in which the dominating sites of the mutants are in the spike protein sequence. The Centers for Disease Control and Prevention and the World Health Organization have primarily classified a system for distinguishing the SARS-CoV-2 variants into two categories, such as variants of concern (VOCs) and variants of interest (VOIs) [20]. The VOCs include four clusters (Alpha, Beta, Gamma, and Delta) with relatively high transmissibility and virulence. The VOIs are the variants exhibiting potentially enhanced transmissibility and virulence, with likely reduced effectiveness of available therapeutics or vaccination, such as Epsilon, Zeta, Eta, Theta, Iota, Kappa, and Lambda.

The requisite components of the SARS-CoV-2 variants (mutations with substitutions or deletions in the spike protein) and calculated charge numbers of each virus variant at $\mathrm{pH} 7.3$ are listed in Table 5. Knowing the high infectivity structure characteristics of SARS-CoV-2 variants is useful to design new medicines for combating the SARS-CoV-2 variants. 
Table 5. The calculated charge numbers of each SARS-CoV-2 variants $[7,28-39]$ at PH 7.3.

\begin{tabular}{|c|c|c|c|c|c|c|c|}
\hline $\begin{array}{c}\text { SARS-CoV-2 } \\
\text { Variant }\end{array}$ & $\begin{array}{c}\mathrm{S}_{\mathrm{RBD}} \\
\text { Mutations }\end{array}$ & $\begin{array}{c}\mathrm{S}_{1} \\
\text { Mutations } \\
\text { Except RBD }\end{array}$ & $\begin{array}{c}\mathrm{S}_{2} \\
\text { Mutations }\end{array}$ & $\begin{array}{c}\text { Charges of } \\
S_{\text {p(RBD) }} \text { at } \\
\text { PH } 7.3\end{array}$ & $\begin{array}{l}\text { Charges of } \\
S_{1} \text { at } P H 7.3\end{array}$ & $\begin{array}{l}\text { WHO } \\
\text { Label }\end{array}$ & Other \\
\hline SARS-CoV-2 & - & - & - & 6.0 & 5.2 & - & - \\
\hline $\begin{array}{c}\text { Alpha } \\
\text { (B.1.1.7) }\end{array}$ & N501Y & $\begin{array}{c}\Delta \mathrm{H} 69, \Delta \mathrm{V} 70, \\
\Delta \mathrm{Y} 144, \\
\mathrm{~A} 570 \mathrm{D}, \\
\mathrm{D} 614 \mathrm{G}, \\
\mathrm{P} 681 \mathrm{H}\end{array}$ & $\begin{array}{c}\text { T716I } \\
\text { S982A } \\
\text { D1118H }\end{array}$ & 6.0 & $5.2+1 *$ & VOC & $\begin{array}{c}\text { D1118H mutation } \\
\text { decreased the } \\
\text { Coulomb repulsion } \\
\text { between } \mathrm{S}_{1} \text { and ACE2 }\end{array}$ \\
\hline $\begin{array}{l}\text { B.1.1.7 + } \\
\text { E484K }\end{array}$ & $\begin{array}{l}\text { E484K } \\
\text { N501Y }\end{array}$ & $\begin{array}{c}\Delta \mathrm{H} 69, \Delta \mathrm{V} 70, \\
\Delta \mathrm{Y} 144, \\
\mathrm{~A} 570 \mathrm{D}, \\
\mathrm{D} 614 \mathrm{G}, \\
\mathrm{P} 681 \mathrm{H}\end{array}$ & $\begin{array}{c}\text { T716I } \\
\text { S982A } \\
\text { D1118H }\end{array}$ & 8.0 & $7.2+1 *$ & VOC & $\begin{array}{l}\text { D1118H mutation } \\
\text { decreased the } \\
\text { Coulomb repulsion } \\
\text { between } \mathrm{S}_{1} \text { and ACE2 }\end{array}$ \\
\hline Beta (B.1.351) & $\begin{array}{l}\text { K417N, } \\
\text { E484K, } \\
\text { N501Y }\end{array}$ & $\begin{array}{c}\text { L18F, D80A, } \\
\text { D215G, R246I } \\
\Delta \mathrm{L} 242, \\
\Delta \mathrm{A} 243, \\
\Delta \mathrm{L} 244, \\
\text { D614G }\end{array}$ & A701V & 7.0 & 8.2 & VOC & \\
\hline Gamma (P.1) & $\begin{array}{l}\text { K417T, } \\
\text { E484K, } \\
\text { N501Y }\end{array}$ & $\begin{array}{l}\text { L18F, T20N, } \\
\text { P26S, D138Y, } \\
\text { R190S, } \\
\text { H655Y, } \\
\text { D614G }\end{array}$ & T1027I & 7.0 & 7.2 & VOC & \\
\hline $\begin{array}{c}\text { Delta } \\
\text { (B.1.617.2) }\end{array}$ & $\begin{array}{l}\text { L452R, } \\
\text { T478K }\end{array}$ & $\begin{array}{c}\text { T19R, } \Delta \mathrm{F} 157, \\
\Delta \mathrm{R} 158 \\
\mathrm{D} 614 \mathrm{G} \\
\text { P681R }\end{array}$ & D950N & 8.0 & $9.2+1 *$ & VOC & $\begin{array}{c}\text { D950N mutation } \\
\text { decreased the } \\
\text { Coulomb repulsion } \\
\text { between } S_{1} \text { and ACE2 }\end{array}$ \\
\hline Delta Plus & $\begin{array}{l}\mathrm{K} 417 \mathrm{~N}, \\
\mathrm{~L} 452 \mathrm{R} \\
\mathrm{T} 478 \mathrm{~K}\end{array}$ & $\begin{array}{c}\text { T19R, } \Delta \mathrm{F} 157, \\
\Delta \mathrm{R} 158 \\
\mathrm{D} 614 \mathrm{G} \\
\mathrm{P} 681 \mathrm{R}\end{array}$ & D950N & 7.0 & $8.2+1 *$ & & \\
\hline $\mathrm{Mu}$ & $\begin{array}{l}\text { R346K, } \\
\text { E484K, } \\
\text { N501Y }\end{array}$ & $\begin{array}{l}\text { D614G, } \\
\text { P681H }\end{array}$ & - & 8.0 & 8.3 & VOI & \\
\hline Lambda & L452Q, F490S & D614G & - & 6.0 & 6.2 & VOI & \\
\hline
\end{tabular}

* Positive charge on $\mathrm{S}_{2}$.

Table 5 shows that the Alpha variant had one more positive charge on Spike compared with SARS-CoV-2, and the N501Y mutation added a tyrosine amino acid residue to interact strongly with $Y 41$ in ACE2 through an aromatic stacking interaction [10]. The $\mathrm{S}_{\mathrm{RBD}}$ of the B.1.1.7 + E484K variant increased 2.0 positive charges compared with Alpha. This increased transmissibility caused an outbreak in the European Union. The $S_{p(R B D)}$ of the Beta variant increased 1.0 positive charge, and $S_{1}$ increased 3.0 positive charges. The infectivity of the Beta variant also increased significantly. The $S_{p(R B D)}$ of the Gamma variant increased 1.0 positive charge, and $S_{1}$ increased 2.0 positive charges. Therefore, the transmissibility of the Gamma variant should be lower than that of the Beta variant. The $S_{p(R B D)}$ of the Delta variant was enhanced 2.0 positive charges, and $S_{1}$ increased 5.0 positive charges, as well as the D950N mutation decreased one negative charge, which is equal to an increase in the positive charge. In addition, the positive charges of two VOIs (Mu and Lambda) and the so-called Delta Plus all increased in some degrees to increase infectivity. Overall, the Delta variant had the greatest increase in positive charge, so the Coulomb attractive force was reinforced. The Delta variant has had the highest transmissibility, being detected in infected patients in different territories and regions $[9,30,40]$. Therefore, the results suggested that the SARS-CoV-2 variants increased their infectivity mainly through adding positive-charge mutations. Thus, through calculating the charge distribution, the infectivity of a novel 
SARS-CoV-2 variant can be preliminarily evaluated. It is very interesting that tumor cells have more negative charges while ordinary cells only have few negative charges or even are neutral [41]. Therefore, because spike proteins have positive charges, the SARS-CoV-2 will attack the tumor cells preferentially, and the tumor cell will be destroyed. Indeed, a 61-year-old man infected with SARS-CoV-2 induced remission from Hodgkin lymphoma without execution of immunochemotherapy or corticosteroid [42] and a Spanish cancer patient infected with SARS-CoV-2 also induced remission afterward.

\subsection{Analysis of SARS-CoV-2 and SARS-CoV Antibodies}

The SARS-CoV-2 spike protein had more positive charges than that of SARS-CoV. We expected that SARS-CoV-2 antibodies would have more negative charges than those of SARS-CoV. Based on the host antibody detection data, we analyzed the electric charges of the amino acid sequences in the three binding regions of the heavy chains and light chains of 61 SARS-CoV and SARS-CoV-2 antibodies, respectively: HVR1 (CDRl), HVR2 (CDR2), and HVR3 (CDR3), in which the molecular structure of the antibodies was collected from $B$ cells of virus-infected humans (http:/ / opig.stats.ox.ac.uk/webapps/covabdab/, accessed on 4 June 2021). As shown in Table 6, among the 61 antibodies, none of the SARS-CoV antibodies with a net charge in the binding region (ABR) is -5 to -7 , but there are twelve SARS-CoV-2 antibodies with charges in that range. The most probable ABR charges are -2 and 0 for the SARS-CoV-2 and SARS-CoV antibodies, respectively, following the above expectation. The more net negative charges on the antibodies contribute to heightening the attraction, combination, and neutralizing reaction.

Table 6. The calculation of antibodies for SARS-CoV-2 and SARS-CoV.

\begin{tabular}{ccccccccccccc}
\hline Net Charge & $-\mathbf{7}$ & $\mathbf{- 6}$ & $\mathbf{- 5}$ & $\mathbf{- 4}$ & $\mathbf{- 3}$ & $\mathbf{- 2}$ & $\mathbf{- 1}$ & $\mathbf{0}$ & $\mathbf{1}$ & $\mathbf{2}$ & $\mathbf{3}$ & $\mathbf{4}$ \\
\hline ABR of SARS-CoV-2 & 4 & 3 & 5 & 3 & 6 & 15 & 8 & 9 & 5 & 1 & 0 & 2 \\
ABR of SARS-CoV & 0 & 0 & 0 & 2 & 7 & 8 & 14 & 17 & 9 & 3 & 0 & 1 \\
\hline
\end{tabular}

\section{Conclusions}

The charge distributions on the spike proteins of SARS-CoV, SARS-CoV-2, variants of concern, and ACE2, as well as some SARS-CoV and SARS-CoV-2 antibodies, were calculated with net charge calculation formulas. The results revealed that $S_{s 1}$ in the SARS-CoV spike protein had net negative charges, $S_{1}$ in the SARS-CoV- 2 spike protein had net positive charges, and ACE2 had many net negative charges. In particular, the Delta variant had the greatest increase in positive charges in $S_{1}$ resulting in the highest infectivity. Thus, the high infectivity mechanism of SARS-CoV-2 is mainly on account of the interaction between positive charges on $S_{1}$ and negative charges on ACE2. Therefore, the results suggested that the SARS-CoV-2 variants increased their infectivity mainly through adding positive-charge mutations. As expected, the binding regions of the SARS-CoV2 antibodies had more negative charges than those of SARS-CoV. Obviously, through calculating the charge distribution, the infectivity of a novel SARS-CoV-2 variant can be preliminarily evaluated.

Author Contributions: Y.L.: writing, review \& editing. T.Z.: data curation. M.L.: software. Y.Z., X.Y.: investigation. G.W.: data curation. F.D.: data curation. F.Z.: calculation. G.Z.: calculation and analysis. All authors have read and agreed to the published version of the manuscript.

Funding: This research was funded by State Key Laboratory for Modification of Chemical Fibers and Polymer Materials fund (YJ202006), the National Advanced Functional Fiber Innovation Center (Jiangsu New Horizon Advanced Functional Fiber Innovation Center Co., Ltd.) fund (No. 2020-fx020022).

Acknowledgments: This study was supported by the State Key Laboratory for Modification of Chemical Fibers and Polymer Materials fund (YJ202006), the National Advanced Functional Fiber Innovation Center (Jiangsu New Horizon Advanced Functional Fiber Innovation Center Co., Ltd.) fund (No. 2020-fx020022).

Conflicts of Interest: The authors declare no conflict of interest. 


\section{References}

1. Chan, J.F.; Lau, S.K.; To, K.K.; Cheng, V.C.; Woo, P.C.; Yuen, K.Y. A familial cluster of pneumonia associated with the 2019 novel coronavirus indicating person-to-person transmission: A study of a family cluster. Lancet 2020, 395, 514-523. [CrossRef]

2. Layne, S.P.; Hyman, J.M.; Morens, D.M.; Taubenberger, J.K. New coronavirus outbreak: Framing questions for pandemic prevention. Sci. Transl. Med. 2020, 12. [CrossRef] [PubMed]

3. Ferretti, L.; Wymant, C.; Kendall, M.; Zhao, L.; Nurtay, A. Quantifying SARS-CoV-2 transmission suggests epidemic control with digital contact tracing. Science 2020, 368. [CrossRef] [PubMed]

4. Barnes, C.O.; West, A.P., Jr.; Huey-Tubman, K.E.; Hoffmann, M.A.; Sharaf, N.G.; Hoffman, P.R.; Koranda, N.; Gristick, H.B.; Gaebler, C.; Muecksch, F.; et al. Structures of Human Antibodies Bound to SARS-CoV-2 Spike Reveal Common Epitopes and Recurrent Features of Antibodies. Cell 2020, 182, 828-842.e16. [CrossRef] [PubMed]

5. Zeyaullah, M.; AlShahrani, A.M.; Muzammil, K.; Ahmad, I.; Alam, S.; Khan, W.H.; Ahmad, R. COVID-19 and SARS-CoV-2 Variants: Current Challenges and Health Concern. Front Genet. 2021, 12, 693916. [CrossRef] [PubMed]

6. Aleem, A.; Samad, A.B.A.; Amy, K.S. Emerging Variants of SARS-CoV-2 and Novel Therapeutics Against Coronavirus (COVID-19). Available online: https:/ /www.ncbi.nlm.nih.gov/books/NBK570580/ (accessed on 18 July 2021.).

7. Winger, A.; Caspari, T. The Spike of Concern-The Novel Variants of SARS-CoV-2. Viruses 2021, 13, 1002. [CrossRef]

8. Li, R.; Pei, S.; Chen, B.; Song, Y.; Zhang, T.; Yang, W.; Shaman, J. Substantial undocumented infection facilitates the rapid dissemination of novel coronavirus (SARS-CoV2). Science 2020, 368, 489-493. [CrossRef]

9. Tolksdorf, B.; Nie, C.; Niemeyer, D.; Röhrs, V.; Berg, J.; Lauster, D.; Adler, J.M.; Haag, R.; Trimpert, J.; Kaufer, B.; et al. SARS-CoV-2 Variants: A Synopsis of In Vitro Effificacy Data of Convalescent Plasma, Currently Marketed Vaccines, and Monoclonal Antibodies. Viruses 2021, 13, 1211. [CrossRef]

10. Wrapp, D.; Wang, N.; Corbett, K.S.; Goldsmith, J.A.; Hsieh, C.-L.; Abiona, O.; Graham, B.S.; McLellan, J.S. Cryo-EM structure of the 2019-nCoV spike in the prefusion conformation. Science 2020, 367, 1260-1263. [CrossRef]

11. Lan, J.; Ge, J.; Yu, J.; Shan, S.; Zhou, H.; Fan, S.; Zhang, Q.; Shi, X.; Wang, Q.; Zhang, L.; et al. Structure of the SARS-CoV-2 spike receptor binding domain bound to the ACE2 receptor. Nature 2020, 581, 215-220. [CrossRef]

12. Wu, C.; Zheng, M.; Yang, Y.; Gu, X.; Yang, K.; Li, M.; Liu, Y.; Zhang, Q.; Zhang, P.; Wang, Y.; et al. Furin: A potential therapeutic target for COVID-19. iScience 2020, 23, 101642. [CrossRef] [PubMed]

13. Jaimes, J.A.; André, N.M.; Millet, J.K.; Whittaker, G.R. Structural modeling of 2019-novel coronavirus (nCoV) spike protein reveals a proteolytically sensitive activation loop as a distinguishing feature compared to SARS-CoV and related SARS-like coronaviruses. J. Mol. Biol. 2020, 432, 3309-3325. [CrossRef] [PubMed]

14. Walls, A.C.; Park, Y.-J.; Tortorici, M.A.; Wall, A.; McGuire, A.T.; Veesler, D. Structure, function and antigenicity of the SARS-CoV-2 spike glycoprotein. Cell 2020, 181, 281-292. [CrossRef] [PubMed]

15. Rota, P.A.; Oberste, M.S.; Monroe, S.S.; Nix, W.A.; Campagnoli, R.; Icenogle, J.P.; Peñaranda, S.; Bankamp, B.; Maher, K.; Chen, M.-H.; et al. Characterization of a novel coronavirus associated with severe acute respiratory syndrome. Science 2003, 300, 1394-1399. [CrossRef] [PubMed]

16. Zhang, L.; Lin, D.; Sun, X.; Curth, U.; Drosten, C.; Sauerhering, L.; Becker, S.; Rox, K.; Hilgenfeld, R. Crystal structure of SARS-CoV2 main protease provides a basis for design of improved $\alpha$-ketoamide inhibitors. Science 2020, 368, 409-412. [CrossRef] [PubMed]

17. Wölfel, R.; Corman, V.M.; Guggemos, W.; Seilmaier, M.; Zange, S.; Müller, M.A.; Niemeyer, D.; Jones, T.C.; Vollmar, P.; Rothe, C.; et al. Virological assessment of hospitalized patients with COVID-2019. Nature 2020, 581, 465-469. [CrossRef] [PubMed]

18. Lam, T.T.-Y.; Jia, N.; Zhang, Y.-W.; Shum, M.H.-H.; Jiang, J.-F.; Zhu, H.-C.; Tong, Y.-G.; Shi, Y.-X.; Ni, X.-B.; Liao, Y.-S.; et al. Identifying SARS-CoV-2 related coronaviruses in Malayan pangolins. Nature 2020, 583, 282-285. [CrossRef]

19. Kraemer, M.U.G.; Yang, C.-H.; Gutierrez, B.; Wu, C.-H.; Klein, B.; Pigott, D.M.; du Plessis, L.; Faria, N.R.; Li, R.; et al.; Open COVID-19 Data Working Group. The effect of human mobility and control measures on the COVID-19 epidemic in China. Science 2020, 368, 493-497. [CrossRef]

20. Han, H.; Yang, L.; Liu, R.; Liu, F.; Wu, K.-L.; Li, J.; Liu, X.-H.; Zhu, C.-L. Prominent changes in blood coagulation of patients with SARS-CoV-2 infection. Clin. Chem. Lab. Med. 2020, 58, 1116-1120. [CrossRef]

21. Li, T.; Lu, H.; Zhang, W. Clinical observation and management of COVID-19 patients. Emerg. Microbes Infect. 2020, 9 , 687-690. [CrossRef]

22. Jin, Z.; Du, X.; Xu, Y.; Deng, Y.; Liu, M.; Zhao, Y.; Zhang, B.; Li, X.; Zhang, L.; Peng, C.; et al. Structure of Mpro from COVID-19 virus and discovery of its inhibitors. Nature 2020, 582, 289-293. [CrossRef] [PubMed]

23. Boopathi, S.; Poma, A.B.; Kolandaivel, P. Novel 2019 coronavirus structure, mechanism of action, antiviral drug promises and rule out against its treatment. J. Biomol. Struct. Dyn. 2021, 39, 3409-3418. [CrossRef] [PubMed]

24. Letko, M.; Marzi, A.; Munster, V. Functional assessment of cell entry and receptor usage for SARS-CoV-2 and other lineage B betacoronaviruses. Nat. Microbiol. 2020, 5, 562-569. [CrossRef]

25. Zhang, G.X.; Li, X.G.; Shu, C.B. A study of the number of charges of nucleic acid and protein. Chin. J. Org. Chem. 2000, 20, 401-406.

26. Shen, T.; Wang, J.L.; Zhao, B.D. Biochemistry; Higher Education Press: Shanghai, China, 1980; Volume 1, pp. 132-134.

27. Li, F.; Li, W.; Farzan, M.; Harrison, S.C. Structure of SARS Coronavirus Spike Receptor-Binding Domain Complexed with Receptor. Science 2005, 309, 1864-1868. [CrossRef] 
28. Volz, E.; Mishra, S.; Chand, M.; Barrett, J.C.; Johnson, R.; Geidelberg, L.; Hinsley, W.R.; Laydon, D.J.; Dabrera, G.; O’Toole, Á.; et al. Assessing transmissibility of SARS-CoV-2 lineage B.1.1.7 in England. Nature 2021, 593, 266-269. [CrossRef]

29. Davies, N.G.; Abbott, S.; Barnard, R.C.; Jarvis, C.I.; Kucharski, A.J.; Munday, J.D.; Pearson, C.A.B.; Russell, T.W.; Tully, D.C.; Washburne, A.D.; et al. Estimated transmissibility and impact of SARS-CoV-2 lineage B.1.1.7 in England. Science 2021, 372, eabg3055. [CrossRef]

30. Tegally, H.; Wilkinson, E.; Giovanetti, M.; Iranzadeh, A.; Fonseca, V.; Giandhari, J.; Doolabh, D.; Pillay, S.; San, E.J.; Msomi, N.; et al. Detection of a SARS-CoV-2 variant of concern in South Africa. Nature 2021, 592, 438-443. [CrossRef]

31. Wibmer, C.K.; Ayres, F.; Hermanus, T.; Madzivhandila, M.; Kgagudi, P.; Oosthuysen, B.; Lambson, B.E.; de Oliveira, T.; Vermeulen, M.; van der Berg, K.; et al. SARS-CoV-2 501Y.V2 escapes neutralization by South African COVID-19 donor plasma. bioRxiv 2021. [CrossRef]

32. Faria, N.R.; Mellan, T.A.; Whittaker, C.; Claro, I.M.; Candido, D.D.S.; Mishra, S.; Crispim, M.A.E.; Sales, F.C.S.; Hawryluk, I.; McCrone, J.T.; et al. Genomics and epidemiology of the P.1 SARS-CoV-2 lineage in Manaus, Brazil. Science 2021, 372, 815-821. [CrossRef]

33. Liu, J.; Liu, Y.; Xia, H.; Zou, J.; Weaver, S.C.; Swanson, K.A.; Cai, H.; Cutler, M.; Cooper, D.; Muik, A.; et al. BNT162b2-elicited neutralization of B.1.617 and other SARS-CoV-2 variants. Nature 2021, 596, 273-275. [CrossRef] [PubMed]

34. Volz, E.; Hill, V.; McCrone, J.T.; Price, A.; Jorgensen, D.; O’Toole, Á.; Southgate, J.; Johnson, R.; Jackson, B.; Nascimento, F.F.; et al. Evaluating the Effects of SARS-CoV-2 Spike Mutation D614G on Transmissibility and Pathogenicity. Cell 2021, 184, 64-75. [CrossRef] [PubMed]

35. Cherian, S.; Potdar, V.; Jadhav, S.; Yadav, P.; Gupta, N.; Das, M.; Rakshit, P.; Singh, S.; Abraham, P.; Panda, S. Convergent Evolution of SARS-CoV-2 Spike Mutations, L452R, E484Q and P681R, in the Second Wave of COVID-19 in Maharashtra, India. bioRxiv 2021. [CrossRef]

36. Lau, S.-Y.; Wang, P.; Mok, B.W.-Y.; Zhang, A.J.; Chu, H.; Lee, A.C.-Y.; Deng, S.; Chen, P.; Chan, K.-H.; Song, W.; et al. Attenuated SARS-CoV-2 variants with deletions at the S1/S2 junction. Emerg. Microbes Infect. 2020, 9, 837-842. [CrossRef] [PubMed]

37. Tang, J.W.; Toovey, O.T.; Harvey, K.N.; Hui, D.S. Introduction of the South African SARS-CoV-2 variant 501 Y.V2 into the UK. J. Infect. 2021, 82, e8-e10. [CrossRef] [PubMed]

38. Chan, K.K.; Dorosky, D.; Sharma, P.; Abbasi, S.A.; Dye, J.M.; Kranz, D.M.; Herbert, A.S.; Procko, E. Engineering human ACE2 to optimize binding to the spike protein of SARS coronavirus 2. Science 2020, 369, 1261-1265. [CrossRef] [PubMed]

39. Leung, K.; Shum, M.H.; Leung, G.M.; Lam, T.T.; Wu, J.T. Early transmissibility assessment of the N501Y mutant strains of SARS-CoV-2 in the United Kingdom October to November 2020. Eur. Surveill. 2021, 26, 2002106. [CrossRef]

40. Garcia-Beltran, W.F.; Lam, E.C.; Denis, K.S.; Nitido, A.D.; Garcia, Z.H.; Hauser, B.M.; Feldman, J.; Pavlovic, M.N.; Gregory, D.J.; Poznansky, M.C.; et al. Multiple SARS-CoV-2 variants escape neutralization by vaccine-induced humoral immunity. Cell 2021, 184, 2372-2383.e9. [CrossRef]

41. Wang, S.; Lu, Y.; Qian, W.H.; Zhao, Y.; Wang, Y.Y.; Zheng, S.Z.; Wang, A.Y. Cell charge: Potential important target of anti-tum or research. Chin. Pharmacol. Bull. 2010, 26, 1541-1544.

42. Sarah, C.; David, T. SARS-CoV-2-induced remission of Hodgkin lymphoma. Br. J. Haematol. 2021, 192, 415. [CrossRef] 